\title{
DENDROCHRONOLOGICAL RECORDS OF DEBRIS FLOW AND AVALANCHE ACTIVITY IN A MID-MOUNTAIN FOREST ZONE (EASTERN SUDETES - CENTRAL EUROPE)
}

\author{
IRENEUSZ MALIK ${ }^{1}$ and PIOTR OWCZAREK ${ }^{2}$ \\ ${ }^{1}$ Faculty of Earth Sciences, University of Silesia, Będzińska 60, 41-200 Sosnowiec, Poland \\ ${ }^{2}$ Institute of Geography and Regional Development, University of Wrocław, Pl. Uniwersytecki 1, 50-137 Wrocław, Poland
}

Received 26 November 2008

Accepted 17 July 2009

\begin{abstract}
Dendrochronological methods were used to determine the frequency of debris flow/avalanche events in a forest zone. A debris flow and avalanche track located in the Eastern Sudetes Mountains (Central Europe) was analysed. The length of the youngest debris flow/avalanche track is about $750 \mathrm{~m}$. Three distinct sections of the debris flow can be identified along the longitudinal section: niche, gully and tongue. The dendrochronological study shows that trees started growing on the margins of the debris flow between 1908 and 1963. Hence, debris flow and/or avalanche events occurred on this slope at the turn of the $19^{\text {th }}$ and $20^{\text {th }}$ centuries. All trees collected from the tongue started growing between 1935 and 1964. However, a large debris flow event took place several years before, most probably during an extraordinary rainfall in June 1921. Following this event, several relatively large debris flows have occurred during the growing season, the strongest dendrochronologically confirmed events occurring in 1968, 1971-1972, 1991, 1997 and probably in 1977. Spring debris flow events induced by snow melt and/or avalanches have occurred in 1994 and 2004. The results suggest that with favourable geological conditions, debris flows can occur very frequently within entirely forested slopes.
\end{abstract}

Keywords: debris flow, avalanche, dendrochronology, mid-mountains.

\section{INTRODUCTION}

Debris flow is an event during which a large volume of a highly concentrated viscous water-debris mixture flows down a slope. Numerous studies have analyzed the causes of debris flow development. The most important factors helping to produce a disturbance of slope equilibrium and the initiation of debris flow are: rainfall (Caine, 1980, Reid et al., 1988, Kotarba, 1992, Fiorillo and Wilson, 2004), snow-melt (Bardou and Delaloye, 2004, Decaulne et al., 2005) and earthquakes (Lin et al., 2003). The debris flow phenomenon occurs particularly frequently in high mountain environments where debris flow activity is often investigated by analysing the wood anatomy of trees (Baumann and Kaiser, 1999; Gärtner et al., 2003, Stoffel et al., 2005). Commonly used dendro-

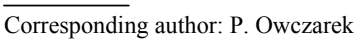

e-mail: piotr.owczarek@geogr.uni.wroc.pl

ISSN 1897-1695 (online), 1733-8387 (print) (C) 2009 GADAM Centre, Institute of Physics, Silesian University of Technology.

All rights reserved. chronological markers in this type of study include abrupt reduction of tree ring width, growth release, scars, as well as the age of adventitious roots. However, no dendrochronological studies have investigated debris flow activity located in mid-mountain areas in the forest zone. A debris flow very rarely appears if its morphological form is wholly situated within a forest zone because root systems prevent slope failures by reinforcing soil and debris cover (Abe and Iwamoto, 1986). Previous research on this type of form was mainly concentrated on analysis of the suppression of debris movement by forests and the influence of trees on the shape of debris flow (May, 2002; Ishikawa et al., 2003, Lancaster and Hayes 2003).

Avalanches often occur within debris flow tracks which remove and wound trees (Malik and Owczarek, 2007). Dendrochronological studies often cover avalanche paths in order to recover particular information about past events and their timing (Carrara, 1979; Casteller et al., 2008). Several indicators are very frequently 
used to reconstruct past avalanche events: (a) scars, (b) tree ring reduction, (c) abrupt growth release, (d) reaction wood, (e) tree age, (f) tree mortality.

The aims of this study are (1) to identify debris flows on the basis of geomorphic forms and (2) to use dendrochronological methods to date debris flow and avalanche events along the debris flow/avalanche track.

\section{STUDY AREA}

\section{General information}

The study area is located in the upper part of the Černy Potok catchment in the Eastern Sudetes Mountains (Central Europe; Figs. 1A and 2). The Sudetes Mountains belong to a vast medium elevation mountain system that formed during the Hercynian Orogeny, an event which produced numerous mountain ranges and isolated massifs in Central and Western Europe. The study area is built of Proterozoic and Old Palaeozoic crystalline and metamorphic rocks, primarily gneisses (Šafăr, 2003). The debrisflow analyzed is located on the eastern slopes of the Červena Hora massif (1337 $\mathrm{m}$ a.s.l.; Fig. 1B). The massif was originally covered by beech (Fagus sylvatica) and mixed forest, gradually giving way to timber-producing spruce (Picea abies) forest at higher altitudes. This vegetation has now been replaced by artificially introduced spruce monocultures covering the slopes. The highest parts of the massif reach above the timberline $(1,250$ $1,300 \mathrm{~m}$ a.s.1.). The average rainfall in the research area is about $1,500 \mathrm{~mm} / \mathrm{yr}$ and more than 50 percent of the total

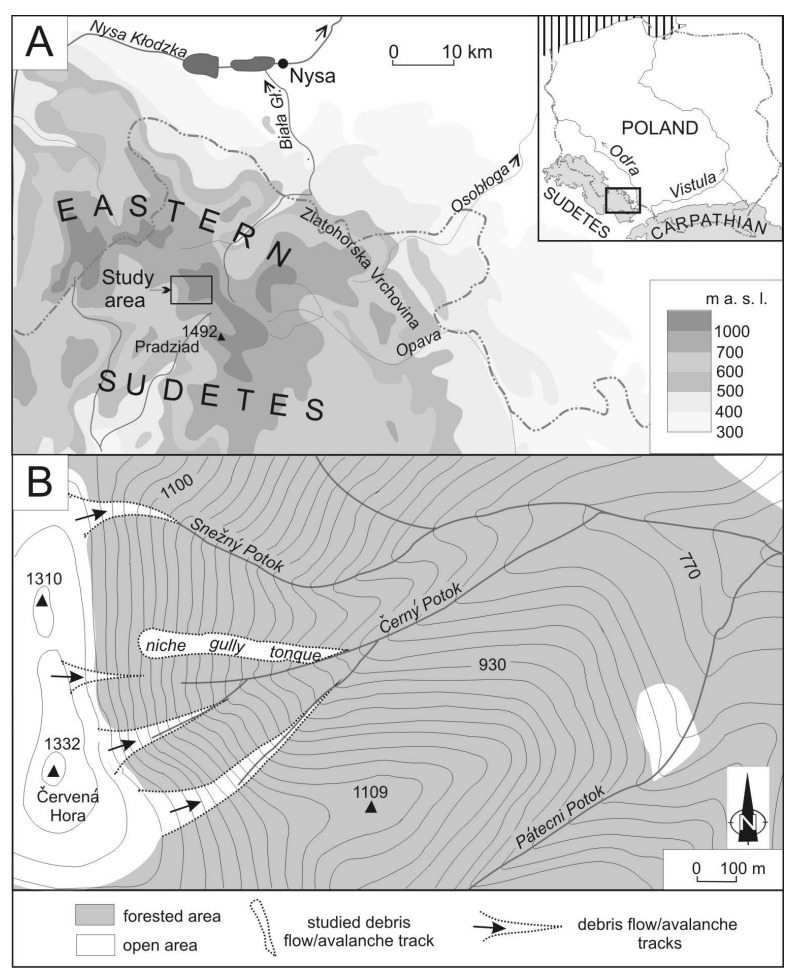

Fig. 1. Location of the debris flow/avalanche track studied in the Eastern Sudetes mountains (A), on the Červena Hora slope (B).

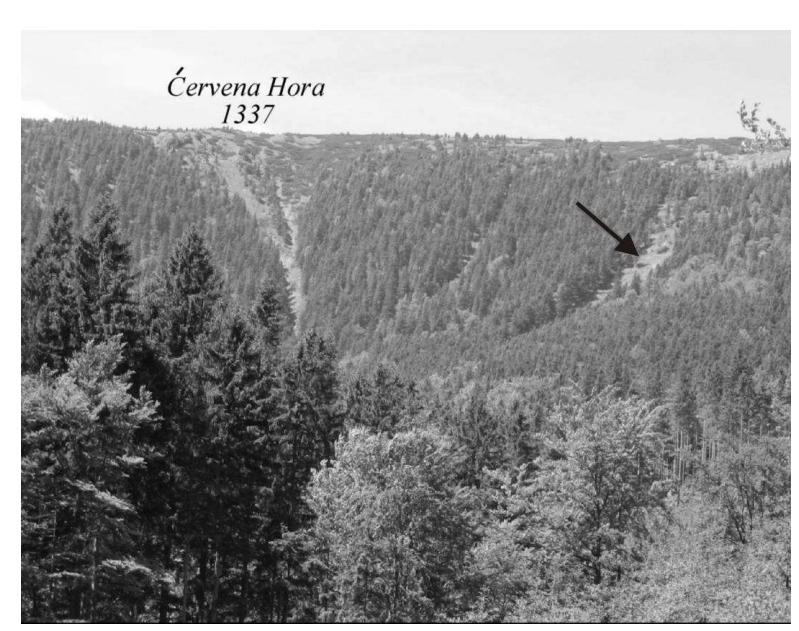

Fig. 2. Debris flow/avalanche track studied on the Cervena Hora massif (black arrow).

precipitation falls during the summer months (Štekl et al., 2001). Two high-water periods are typically observed in the rivers in the Sudetes Mountains. The June/July flood, caused by heavy rains, tends to be particularly high (Polách and Gába, 1998). The springtime snow-melt flood is spread over a longer period of time and comes from the thawing of the thick snow cover. The great thickness of snow and relatively steep slopes are determining factors governing the avalanches that sometimes occur on the Červena Hora massif (information from Czech Republic Forestry Services).

\section{Debris flow/avalanche track morphology}

The track under study has typical relief for debris flow activity, despite the avalanches that occur on the slope. Therefore in the rest of this paper we have used terms characteristic for debris flow to describe features of the track. The debris flow/avalanche track is located below the timberline on the eastern slope of the Červena Hora massif (Fig. 1B). The steep slope gradient and the consequent foliation of mica schists with a thick cover of periglacial slope material are conducive to a repetition of the flow. This part of the Sudetes Mountains is covered by dense forest vegetation. The debris flows and avalanches wound and sometimes break trees thereby also creating suitable conditions for the events that follow. The length of the youngest debris flow/avalanche track is about $750 \mathrm{~m}$. Three distinct sections can be distinguished in its longitudinal profile: the debris flow niche, gully and tongue (Fig. 1). The upper part of the debris flow forms a shallow niche with a maximum width of $55 \mathrm{~m}$ and a length of about $130 \mathrm{~m}$. Elongated lobes are observed in this part of the landform. The debris flow gully stretches downstream of the niche and forms a distinct erosion trough $4-5 \mathrm{~m}$ in depth and $24-35 \mathrm{~m}$ wide (Fig. 3). The lower section is composed of the debris flow tongue, which fills a 150 m length of the Černy Potok river channel. An accumulation of mineral deposits as well as a large accumulation of logs several meters in thickness have been created in this deposition zone. 


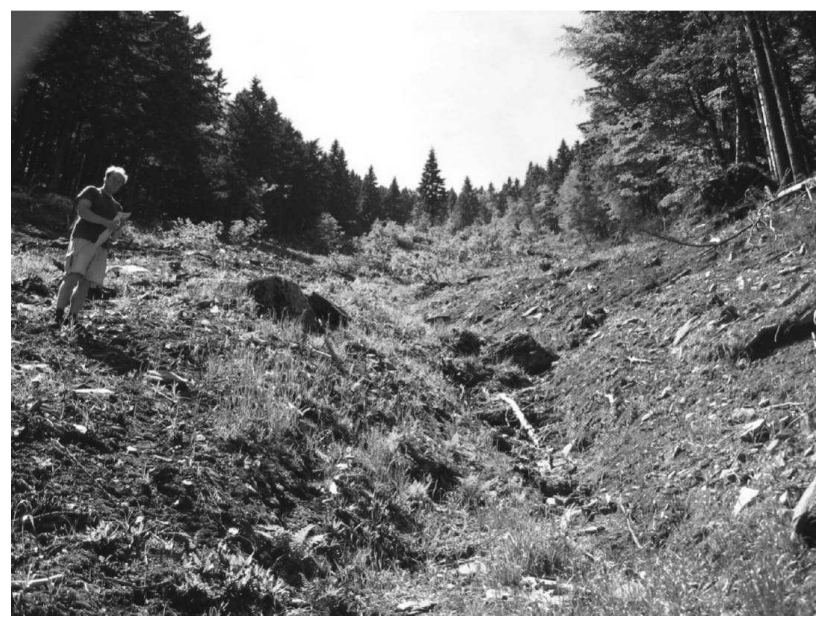

Fig. 3. The gully of the debris flow track/avalanche studied in the Červena Hora massif.

\section{METHODS}

\section{Site selection and sampling strategy}

An isolated plant island about $20 \mathrm{~m}$ in diameter (site 1) is located in the debris flow/avalanche track on the Črvena Hora slope. This lies at a distance of 420-510 m above a large accumulation of logs (Fig. 4). Beech sprouts growing on the island are wounded during colluvium transport and the scars so produced can give us information about erosion events.

Sites 2, 3, and 4 were located respectively $120-250 \mathrm{~m}$, $2-57 \mathrm{~m}$, and $2-5 \mathrm{~m}$ above the large accumulation of $\operatorname{logs}$ (Fig. 4). The spruce trees sampled were growing on the border between the forest and the debris flow/avalanche track. All of them had scars on the side facing the colluvium transport zone, about $0.5-5 \mathrm{~m}$ in height (Fig. 5). For tree ring reduction dating we assumed that they produce reduced tree rings after the spruce trees were wounded, so that the age of the scar can be dated. A more precise method for dating spruce wounding is the analysis of the age of the callus tissue bordering the wound and the analysis of tangential rows of traumatic resin ducts within disks collected directly from the edges of the injury. Unfortunately the study area is under protection and we did not get permission from CHKO - Chroniony Krajobrazowy Obszar (Area of Protected Landscape) to collect disks from living trees.

Three sites (5, 6 and 7) were situated in places where there is a large accumulation of logs. Site 5 was located in the marginal zone of a debris flow/avalanche track, between 120 and $240 \mathrm{~m}$ above the large accumulation of logs (Fig. 4). Sites 6 and 7 were located within the large accumulation of $\operatorname{logs}$ in the lower part of the debris flow/avalanche track. Trees fell as a result of colluvium and snow transport and the times of their deaths record the time of the material transport and avalanche events.

\section{Sample collection}

Samples consisting of $10 \mathrm{~cm}$ lengths of the thickest beech sprouts were collected at site 1 . The ages of 8 beech sprouts growing on site 1 and of 6 scars were measured. A core was taken at $0.4 \mathrm{~cm}$ above ground level from a single spruce growing on this site. We collected two cores about $1.2 \mathrm{~m}$ above ground level along an axis parallel to the slope gradient and from opposite sides of 19 trees at sites 2, 3 and 4 .

The authors determined the position of logs in relation to other logs and debris flow sediments at sites 5, 6 and 7, and classified the logs according to whether they lay partially buried under sediment or entirely on it. In the case of logs lying under the sediment, the depth of burial was measured. Discs were taken from $16 \operatorname{logs}$ about 0.3$0.5 \mathrm{~m}$ above the root system.

\section{Analyses of material collected}

The ages of beech sprouts and spruce collected at sites 1-4 were measured by counting rings under a binocular microscope. Graphs were prepared presenting tree ring width variation in order to determine tree ring suppression within cores collected from spruce sampled along the debris flow/avalanche track. Ring variation from every wounded tree was matched to the chronology which had previously been prepared based on data from local spruce trees (1910-2005; Malik and Owczarek, 2007). Comparison of individual ring curves and the local chronology was necessary because mechanical stress is not the cause of every tree ring reduction (Schwiengruber, 1996). Sometimes climatic factors are responsible for ring reduction and these are clearly recorded in the local chronology and can easily be separated from other types of reduction. The Gleichlaufigkeit (GLK - parallel agreement) test was used for validation (Huber, 1943) both in case of trees and in the case of logs. It was assumed that tree growth reduction occurred when the Tree Growth Reduction Intensity Coefficient (TGRIC) was more than 1.5. TGRIC was introduced by the authors to show the different intensity of reduction recorded in trees. TGRIC is defined as the relation between the mean width of the three following rings from the tree sample being studied and the mean width of the same three following rings from a local chronology (Fig. 6). The authors selected three classes of TGRIC:

1) weak reduction, when TGRIC is between 1.5 and 2 .

2) moderate reduction, when TGRIC is between 2 and 5 .

3) strong reduction, when TGRIC is more than 5 .

Taking cores $2 \mathrm{~m}$ above ground level reduced the estimated age of trees below the actual age. The age of 15 spruce trees, about $2 \mathrm{~m}$ in height, was measured and this showed that spruce need a minimum of 9 years to reach this height. Therefore 9 years were added to the number of years counted within the cores in order to assess the age of spruce more precisely. Where the borehole did not pass exactly centrally through the tree, the size of annual growth increments was interpolated by averaging the sizes of the three oldest rings found within the core. Subsequently, the number of average annual growth increments within the radius of the circle delineated by the oldest annual growth increment included in the core was calculated. Tree ring width curves were constructed from discs collected from logs lying along the debris flow/avalanche track. Tree ring curves were fitted to the local chronology and the death of trees currently lying as $\log$ in the debris flow/avalanche track was dated. 


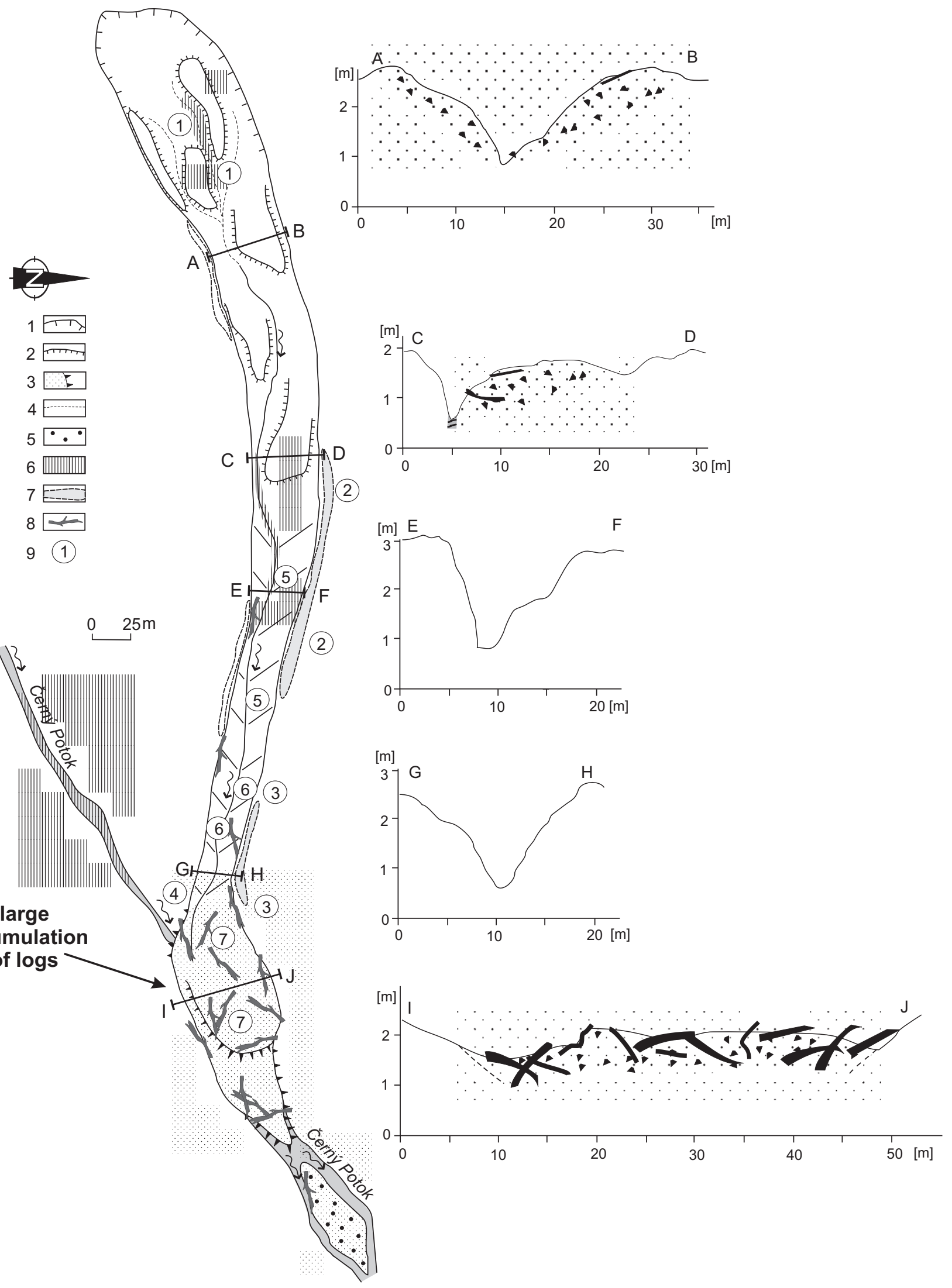

Fig. 4. Morphological sketch and cross-section of the debris-flow/avalanche track under study. 1 - scar, 2 - edges of accumulation forms, 3 - debrisflow tongue, 4 - periodically drained small gullies, 5 - depositional river channel forms, 6 - bedrock outcrops, 7 - levees, 8 - coarse woody debris, 9 - location of the dendrochronological study sites. 
The authors studied the stage of formation of the last tree ring within logs. We assumed that the tree died during the growing season when the last tree ring had not been entirely produced. In the upper parts of the Jeseniki Mountains the growing season lasts on average from June to August (Šafăr, 2003). When the authors only identified early wood within the tree ring, this meant that the tree had died at an early stage in the growing season. When a tree only produced part of the late wood, the tree had died in the later part of the growing season. Trees had died in the dormant season when the last ring was completely formed. Similar studies were carried out by Perret et al. (2006) on samples collected in order to reconstruct rockfall activity in the Swiss Prealps.

\section{RESULTS}

A detailed map of the track was constructed (Fig. 4). All of the trees sampled had started growing in the marginal zones of the debris flow/avalanche track between 1912 and 1963 (Table 1). Older trees had colonized the upper part of the track. Clear and numerous tree ring reduction occurred in 1967-68, 1972, and 1975-1977 (Table 1). Examples of individual tree ring series from wounded trees growing on the margin of the debris flow/avalanche track are presented in Fig. 8. Most cored trees recorded moderate tree ring reduction (Table 1). In general, the greatest TGRIC's were recorded in the case of trees growing at sites 3 and 4 .

Table 1. Tree position and their years of ring reduction at sites 2-4 located on the Cervena Hora slope.

\begin{tabular}{|c|c|c|c|c|c|}
\hline site & tree number* & $\begin{array}{c}\text { distance above large } \\
\text { accumulation of logs } \\
{[\mathrm{m}]}\end{array}$ & $\begin{array}{l}\text { years when trees } \\
\text { started growing }\end{array}$ & $\begin{array}{l}\text { years when tree ring } \\
\text { reduction started }\end{array}$ & $\begin{array}{l}\text { Tree Ring Reduction } \\
\text { Intensity Coefficient } \\
\text { (TGRIC) }\end{array}$ \\
\hline \multirow[t]{16}{*}{2} & $(\mathrm{~L})-(\mathrm{B} 20)$ & 145 & 1923 & 1933 & 2.9 \\
\hline & & & & 1942 & 2.6 \\
\hline & & & & 1948 & 2.3 \\
\hline & & & & 1968 & 2.9 \\
\hline & & & & 1975 & 3.6 \\
\hline & & & & 1977 & 2.9 \\
\hline & $(\mathrm{L})-(\mathrm{B} 21)$ & 175 & 1912 & 1922 & 1.5 \\
\hline & & & & 1942 & 3.2 \\
\hline & & & & 1972 & 3.2 \\
\hline & $(\mathrm{L})-(\mathrm{B} 22)$ & 180 & 1917 & 1924 & 2.7 \\
\hline & & & & 1941 & 3.4 \\
\hline & & & & 1975 & 3.5 \\
\hline & $(\mathrm{L})-(\mathrm{B} 23)$ & 200 & 1928 & 1941 & 3.1 \\
\hline & & & & 1952 & 8.9 \\
\hline & & & & 1975 & 9.2 \\
\hline & $(\mathrm{L})-(\mathrm{B} 25)$ & 250 & 1952 & 1973 & 2.9 \\
\hline \multirow[t]{13}{*}{3} & $(\mathrm{~L})-(\mathrm{B} 8)$ & 2 & 1946 & 1983 & 2.2 \\
\hline & $(\mathrm{L})-(\mathrm{B} 9)$ & 14 & 1950 & 1997 & 2.2 \\
\hline & $(\mathrm{L})-(\mathrm{B} 10)$ & 24 & 1945 & - & - \\
\hline & $(\mathrm{L})-(\mathrm{B} 12)$ & 24 & 1939 & 1972 & 10.6 \\
\hline & $(\mathrm{L})-(\mathrm{B} 13)$ & 34 & - & - & - \\
\hline & $(\mathrm{L})-(\mathrm{B} 14)$ & 42 & 1942 & 1972 & 8.5 \\
\hline & $(\mathrm{L})-(\mathrm{B} 15)$ & 46 & 1937 & 1952 & 3.1 \\
\hline & & & & 1967 & 1.5 \\
\hline & & & & 1986 & 1.5 \\
\hline & $(\mathrm{L})-(\mathrm{B} 17)$ & 46 & 1941 & 1967 & 4.3 \\
\hline & $(\mathrm{L})-(\mathrm{B} 18)$ & 46 & 1942 & - & - \\
\hline & (1) $-(\mathrm{B} 19)$ & 57 & 1940 & 1972 & 4.9 \\
\hline & $(L)-(D \mid Y)$ & & 1940 & 1983 & 2.4 \\
\hline \multirow[t]{4}{*}{4} & $(\mathrm{P})-(\mathrm{B} 1)$ & 4 & 1963 & 1998 & 2.2 \\
\hline & $(\mathrm{P})-(\mathrm{B} 2)$ & 2 & 1962 & 1991 & 2.4 \\
\hline & $(\mathrm{P})-(\mathrm{B} 3)$ & 3 & 1961 & - & - \\
\hline & $(\mathrm{P})-(\mathrm{B} 4)$ & 5 & 1960 & 1976 & 15.8 \\
\hline
\end{tabular}

*(P) - right side of debris flow track; $(L)$ - left side of debris flow track 
Table 2. Position and dating of logs on the Červena Hora slope.

\begin{tabular}{|c|c|c|c|c|c|c|c|}
\hline site & $\begin{array}{c}\log \\
\text { number }\end{array}$ & $\begin{array}{l}\text { distance above large } \\
\text { accumulation of logs [m] } \\
\text { and location in relation } \\
\text { to debris flow track }\end{array}$ & $\begin{array}{l}\text { position in } \\
\text { relation to } \\
\text { sediments }\end{array}$ & $\begin{array}{l}\text { assessed year } \\
\text { when trees } \\
\text { started grow- } \\
\text { ing }\end{array}$ & $\begin{array}{l}\text { year of } \\
\text { death of } \\
\text { trees }\end{array}$ & $\begin{array}{l}\text { part of the grow- } \\
\text { ing season when } \\
\text { tree was fallen** }\end{array}$ & $\begin{array}{c}\text { gleichlaufigkeit } \\
\text { GLK (\%) }\end{array}$ \\
\hline \multirow[t]{6}{*}{5} & (K20) & $(\mathrm{L})-240$ & on sediments & 1932 & 1968 & EGS & 66 \\
\hline & (K19) & $(\mathbf{S})-240$ & on sediments & 1920 & 1968 & EGS & 71 \\
\hline & (K18) & $(\hat{S})-210$ & $\begin{array}{l}\text { under sediments } \\
-0.3 \mathrm{~m}\end{array}$ & 1958 & 1994 & DS & 67 \\
\hline & (K17) & $(P)-170$ & on sediments & 1944 & 1987 & DS & 72 \\
\hline & (K15) & $(\dot{S})-160$ & on sediments & 1956 & 1991 & DS & 71 \\
\hline & (K14) & $(S)-120$ & $\begin{array}{c}\text { under sediments } \\
-0.3 \mathrm{~m}-0.7 \mathrm{~m}\end{array}$ & 1908 & 1990 & LGS & 54 \\
\hline \multirow[t]{9}{*}{6} & (K13) & $(P)-93$ & $\begin{array}{c}\text { under sediments } \\
-0.3 \mathrm{~m}-0.5 \mathrm{~m}\end{array}$ & 1940 & 1994 & DS & 62 \\
\hline & (K12) & $(L)-90$ & on sediments & 1937 & 1994 & DS & 54 \\
\hline & (K11) & $(\mathbf{S})-85$ & on sediments & 1918 & 1994 & DS & 60 \\
\hline & (K10) & $(\mathrm{L})-80$ & on sediments & 1909 & 1991 & LGS & 48 \\
\hline & (K9) & $(L)-80$ & $\begin{array}{c}\text { under sediments } \\
-0.3 \mathrm{~m}-0.3 \mathrm{~m}\end{array}$ & 1909 & 1994 & DS & 74 \\
\hline & (K8) & $(L)-65$ & $\begin{array}{c}\text { under sediments } \\
-0.3 \mathrm{~m}-0.5 \mathrm{~m}\end{array}$ & 1954 & 1994 & DS & 69 \\
\hline & (K7) & $(P)-51$ & on sediments & 1952 & 1997 & EGS & 65 \\
\hline & $(\mathrm{K} 6)$ & $(\mathbf{S})-41$ & on sediments & 1944 & 1997 & DS & 59 \\
\hline & (K5) & $(P)-40$ & on sediments & 1946 & 1997 & EGS & 53 \\
\hline \multirow[t]{4}{*}{7} & (K4) & $(S)-0$ & on sediments & 1951 & 1997 & EGS & 66 \\
\hline & (K3) & $(S)-0$ & on sediments & 1949 & 1985 & DS & 71 \\
\hline & (K2) & $(\mathrm{L})-0$ & on sediments & 1885 & 2004 & DS & 58 \\
\hline & (K1) & $(\hat{S})-0$ & on sediments & 1958 & 2004 & DS & 59 \\
\hline
\end{tabular}

${ }^{*} P$ - right side, $L-$ left side, $S-$ middle

${ }^{* *} D S$ - dormant season, EGS - early growing season, LGS - late growing season.

The date when trees currently lying as logs on the debris flow/avalanche track had started growing lay approximately in the period between 1885 and 1958 (Table 2). The trees had died in the period from 1968 to 2004. Groups of trees also fell in 1994 and 1997. Most trees fell during the dormant season, but trees which had died earlier, for example in 1968 and 1997, fell during the first part of the vegetation season. GLK values vary between 48 and 74 (Table 2).

\section{DISCUSSION}

Precision of debris flow and avalanche dendrochronological dating

We can estimate the age of a tree growing on a place where debris flows or avalanches have already occurred. We also can estimate the time which passes between a debris flow or avalanche event and a tree germinating. It should be assumed that at least several or a dozen years must have passed to allow the first trees to germinate. A study carried out in the neighbouring Karkonosze massif has shown that trees can colonize a levee 7 years after a debris flow event (Dunajski, 1998). Finally it seems that the time which passes after a debris flow event and

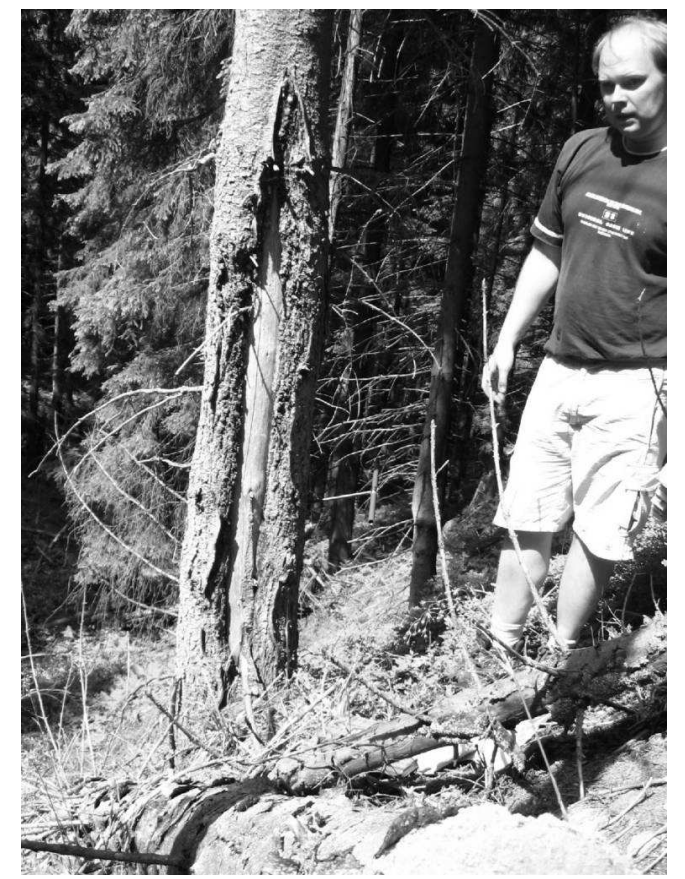

Fig. 5. One of the wounded trees growing on the marginal zone of the debris flow/avalanche track. 


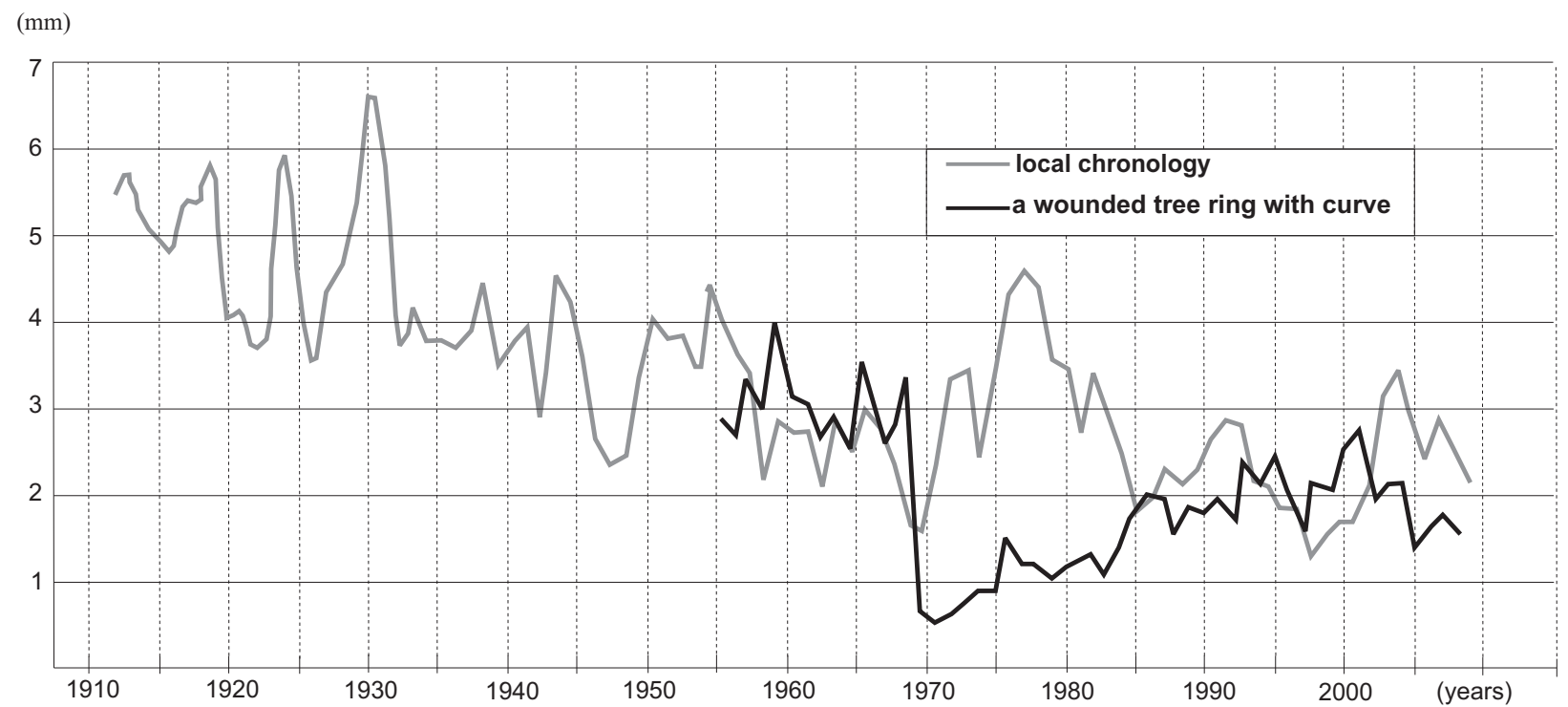

Fig. 6. One Three following tree rings ("empty" points) within a local chronology and in one of the samples used in the calculation of TGRIC (in this example the mean width of the three following rings from the local chronology $=2.33$, the mean width of the three following reduced rings from the wounded tree sample $=0.54$, the relation of the mean local chronology tree rings to mean wounded tree sample $(T G R I C)=4.31(2,33 / 0,54)$.

avalanches is different dependent on the conditions on the site, for example: the degree of rock weathering, slope declination, insolation, water conditions etc. Therefore every attempt to assess the time which had passed between debris flow and avalanches and the first trees germinating could result in an error.

A factor limiting the usefulness of dendrochronological dating of debris flow and avalanches is the age of the trees and sprouts. For example, the age of sprouts on site 1 is from 24 to 58 years, so it is possible to record debris flow and avalanches up to a maximum of 50 years. Trees sampled at other sites are from 42 to 93 years old, which means the authors could only reconstruct the last century of debris flow and avalanche activity on the Červena
Hora slope.

A tree often starts to produce a reduced ring a year after a wound occurs, especially when the tree was injured after the growth season. A similar reaction has been observed on riparian alders which had tilted as a result of erosion (Malik, 2006). Wounded trees may even produce reduced rings with a two year delay after the event which caused the reduction. More precise dating of an event which wounded a tree is obtained by the analysis of a half-disk collected with the bordering callus tissue.

It is possible to obtain a wrong tree ring reading within a core taken from a wounded tree. Sometimes it seems that ring reduction is induced by mechanical stress and climatic factors which overlap each other. Such a

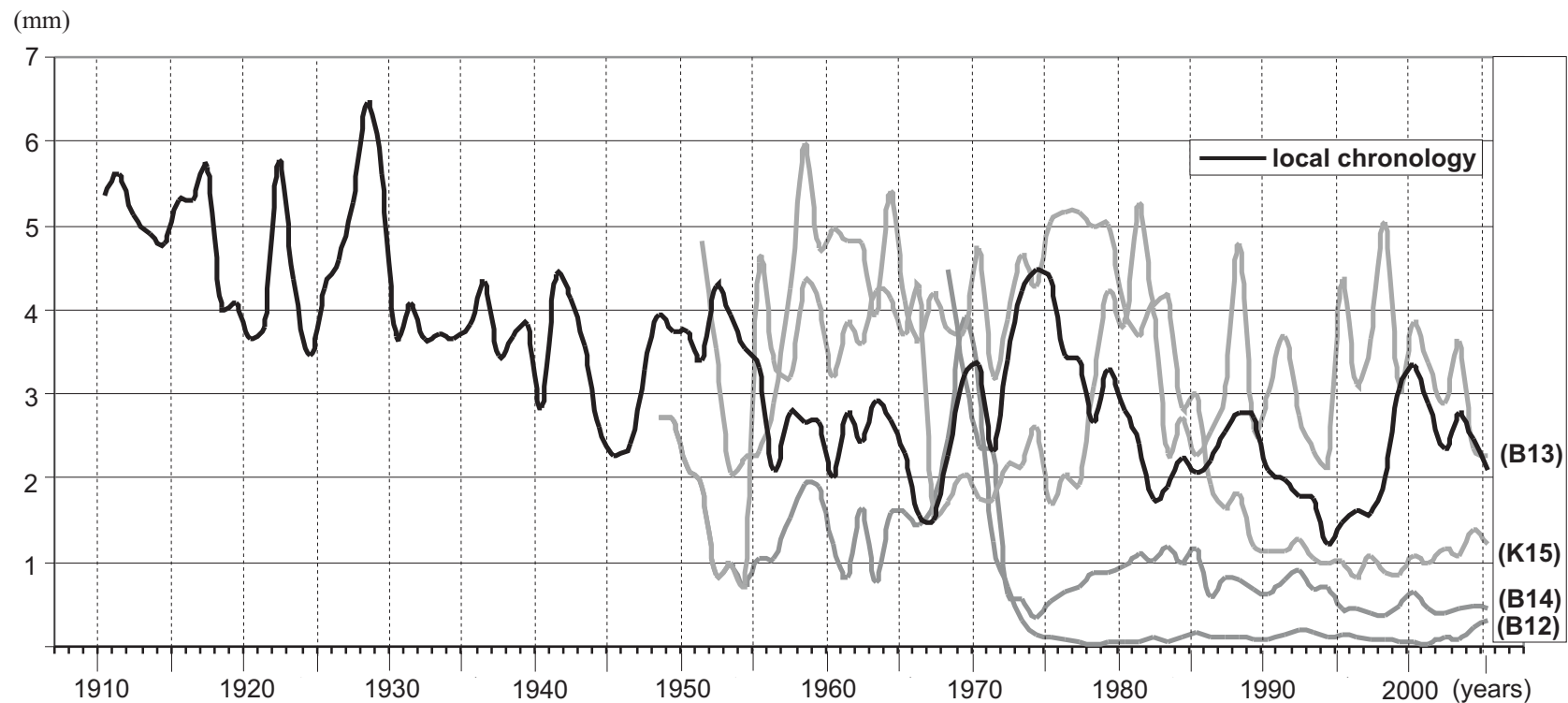

Fig. 7. Ring width curves of trees from the debris flow/avalanche track studied (trees B12-B15) and the local chronology. 
situation occurred for example in the case of tree (B15) in 1989 , so it is difficult to identify the year when the tree reacted to mechanical stress (Fig. 7). Log dating is precise when GLK is more than $65 \%$. This occurred in 10 out of the 19 samples analysed, in the case of the other samples GLK was less than $65 \%$. No reduced tree growth data agree with the local chronology but when ring reduction starts, GLK is very low. For example ring width variation of $\log$ B14 agrees with the local chronology (GLK is $82 \%$ ), but since reduction occurred, GLK is very low $(36 \%)$. Sometimes the last rings are very strongly reduced. This suggests that the tree had been wounded before it died but there are no scars within the tree stem. Perhaps the tree was alive after falling because soil material was still stuck between its roots. This is possible because the authors have observed living fallen trees lying on the slopes of the Eastern Sudetes. Such a situation was observed for log number 10 in which the last four rings of the tree were extremely thin.

\section{Times and conditions of debris flows and avalanches occurring on the Červena Hora slope}

The historical record shows that many debris flows on the Červena Hora slopes occurred after the extraordinary rainfall in June 1921 (Fig. 8). Precipitation exceeded $200 \mathrm{~mm} / 2$ hours (Štekl et al., 2001) at the time when the

debris flow track studied originated, or at least was widened if it is assumed that it had already been formed before.

The oldest trees grew in the middle part of the debris flow gully, 150-250 m away from the large accumulation of logs. These trees germinated between 1912 and 1932, which means that debris flows or avalanches occurred at the turn of the $19^{\text {th }}$ and $20^{\text {th }}$ centuries, otherwise the trees would be older. Trees growing in some locations on neighbouring slopes are 200 years old.

The separate plant island at site 1 started growing at the end of the 1940s, so we can presume that the debris flows or avalanches which were recorded by dendrochronological data as being created in 1941-42 or earlier included the area of the island. Probably the debris flow which wounded trees at the site had occurred on $19^{\text {th }}$ April 1940 when great rainfall events described by Štekl et al. (2001) occurred. On the slopes located above Domaszow ( $3 \mathrm{~km}$ to the southeast of the area studied), the debris flow track was created during a $127.5 \mathrm{~mm}$ rainfall event, however we can't exclude the possibility that avalanches occurred at the beginning of the 1940s.

The great majority of the trees and sprouts studied (35 from 46) started growing between 1935 and 1964. All of the trees growing on the left side of the debris flow/avalanche track, and 2-57 $\mathrm{m}$ above the large accumulation of logs started growing during that time. It follows that debris flows had occurred on the slope several years before 1935. It is highly probable that an extraordinary debris flow occurred on the slope in 1921. After the debris flow in 1921, trees started to colonize the zone along the margin of the debris track studied.

Two tree ring reductions were recorded in the tree stems growing on the upper and middle parts of the debris flow/avalanche track in 1952 (Fig. 9). These must be related to debris flows that occurred on $5^{\text {th }}$ July 1951 , because numerous debris flows were observed within the Keprnik massif, $3 \mathrm{~km}$ away from the Červena Hora slope, (Polách and Gába, 1998).

Trees sampled on the right side of the debris flow/avalanche track adjoining a large accumulation of logs had started growing between 1960 and 1963. This means that a debris flow or avalanche event must have taken place several or up to a dozen years before, perhaps in 1951, which felled trees on this part of the slope.

Debris flows occurred on the slope studied in 19671968, 1971-1973 and 1975-78 (Fig. 9) and these can be identified in numerous dendrochronological age determinations. In general, the most frequent debris flows were recorded in 1967-78. This means that slope processes were particularly active at that time. By the mid 1960s trees stopped colonising the zone along the margin of the debris flow/avalanche track, which confirms the great debris flow activity at that time. After the mid 60s trees were very often wounded (Fig. 9). The results have shown that the event which occurred in 1967-1968 caused some trees to fall and that the trees had fallen during the early growing season (Table 2). This means that trees were felled by debris flow and not by avalanches. The event was additionally demonstrated because 4 tree ring reductions were recorded in 1968 (Fig. 9). It is difficult to show which rainfall event was responsible for the debris flow occurring, there is no information in the historical and meteorological sources about any rainfall events at the end of the 1960s. Perhaps regolith transport occurred as a result of a local precipitation event.

The debris flow which followed was induced by a rainfall event which occurred on $29^{\text {th }}$ May 1971 (Fig. 9). In total $120-160 \mathrm{~mm}$ of precipitation fell in the Eastern Sudetes mountains area, and numerous debris flows occurred on many slopes (Gába, 1992; Štekl et al., 2001). In 1971 two beech sprouts were wounded and four major tree ring reductions were recorded within spruce stems in 1972 (Fig. 9). It seems that the 100-120 mm/day precipitation which occurred on $20^{\text {th }}$ August 1972 induced the next debris flow. The next time a tree ring reduction was recorded was in 1975-1977, and we cannot exclude the possibility that the rainfall occurring on $31^{\text {st }}$ July 1977 caused a reaction in the trees (Štekl et al., 2001). Four trees lying as logs on the track only produced early wood in 1997. This means that debris flow occurred on the slope in 1997. The debris flow occurred as a result of great precipitation occurring in the Eastern Sudetes over the period $6^{\text {th }}-9^{\text {th }}$ July 1997 . Regolith was redeposited on numerous slopes and valleys during this event (Zieliński, 2003).

Younger regolith transport events confirmed by dendrochronological dating could be the result of snowinduced debris flows or avalanches. Four logs felled in 1994 and one felled in 1991 were buried by sediments up to $0.7 \mathrm{~m}$ in depth. Simultaneously most of the trees felled in the 1980s and 1990s have produced an entire last tree ring, despite the fact that lots of debris flows occurred on neighbouring slopes in 1991. This means that the logs fell outside the growing season, most probably as an effect of avalanches or snow melt which was connected with regolith transport. 


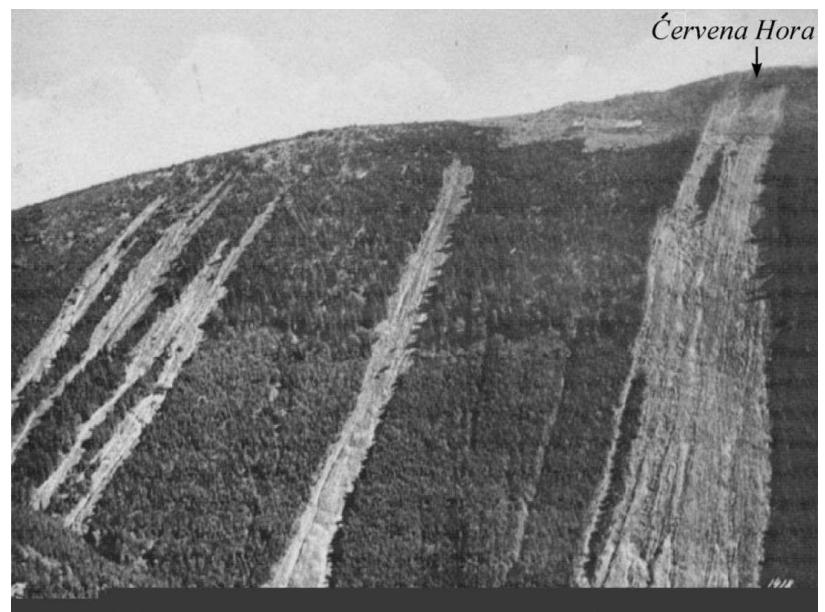

Fig. 8. Debris flow tracks in the Cervena Hora massif after the intensive precipitation event in June 1921.

The oldest logs fell in 1968, others fell in 1991, 1994 and 1997 (Fig. 9). When we come down slope the logs get younger and younger. This means that when logs fall, most of them reach the great accumulation of logs, where recumbent logs record debris flows and/or avalanche events. During the transport, part of the log mass is thrown aside onto marginal parts of the debris flow/avalanche track. They did not always get transported in the following debris flows or avalanches, therefore relatively old logs lie in the upper part of the slope.

\section{Debris flow and avalanche activity in the Eastern Sudetes}

Numerous mineral material and snow transport corridors function within completely forested slopes in the Eastern Sudetes mountains. Corridors occurred in the closed forest as a result of debris flow events, because it is not possible for avalanches to form on forested slopes. Regolith is only removed from the axis of the debris flow track and levees are formed on the margins of the track. When a corridor is opened on a slope, avalanches can occur. They widen a corridor because trees are cleared from the margins of a track. Similar corridors where avalanches and debris flow occur together were described by Butler (2001). When the regolith located in the margin of track is exposed from beneath trees, it is prone to transport so mineral material is transported as debris flow, or by avalanches during appropriate meteorological conditions, and the corridor is widened. Sometimes when debris flow or avalanches are not occurring on a corridor, trees colonize the margins of tracks. The presence of regolith on the marginal zone of the track allows fast tree growth (sometimes less than decades). It is difficult to say if it is possible to completely close the corridor. If we take the presence of bedrock in the middle part of the corridor into consideration, the closing of the corridor is probably only possible in the long term when weathering forms new regolith and soil. It would appear more likely that the corridor is open all the time and material is systematically transported, so that after a long time the cor-

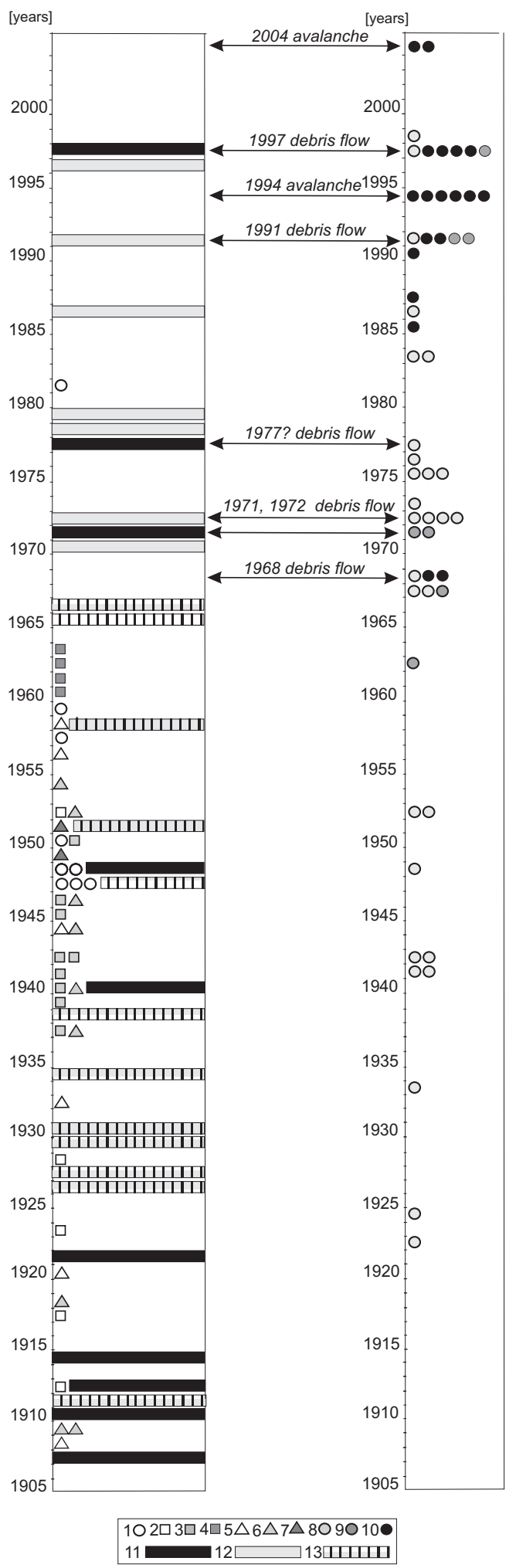

Fig. 9. The results of dendrochronological dating of debris flows and avalanche activity on the Cervena Hora slope and the main precipitation and flood events that occurred in the Eastern Sudetes mountains. 1 - age of beech sprouts (site 1), 2 - age of trees (site 2), 3-age of trees (site 3), 4 - age of trees (site 4), 5-age of trees/logs (site 5), 6 age of trees/logs (site 6), 7 - age of trees/logs (site 7), 8 - tree ring reductions (sites 1-7), 9 - scars on beech sprouts (site 1), 10 - age of logs (sites 5-7), 11 - rainfall events: more than $100 \mathrm{~mm} /$ day recorded in Eastern Sudetes (Štekl, 2001), 12 - rainfall events between 20 and $100 \mathrm{~mm} /$ day recorded in the Eastern Sudetes (Štekl, 2001), 13 relatively small rainfall/flood events recorded in the Eastern Sudetes (Polách and Gába, 1998). 
ridors are transformed into valleys which cross the mountain massif.

\section{CONCLUSIONS}

The debris flow/avalanche track studied was formed or most probably widened in 1921 during an extraordinary rainfall event. After the event, trees gradually colonized the margins of the debris flow track until 1968 when the first debris flow was strongly recorded in the tree rings. Since that time debris flows have proved very common (1968, 1971-1972, 1977?, 1991, 1997). Material transport events which occurred in 1994 and 2004 were induced by avalanches or snow melt debris flow. In favourable geological conditions regolith could even be transported in closely forested slopes of the midmountain zone. Regolith transport corridors function periodically on the slopes during periods of great precipitation frequency and intensity.

Avalanche and/or snow melt debris flow can occur in the corridors. During debris flow events and avalanches trees are cleared from the margins of debris and corridors are widened.

\section{REFERENCES}

Abe K and Iwamoto K, 1986. An evaluation of tree-root effect on slope stability by tree-root strength. Journal Japanese Forest Society 68 : 505-510.

Bardou E and Delaloye R, 2004. Effects of ground freezing and snow avalanche deposits on debris flows in alpine environments. Natural Hazards and Earth System Sciences 4: 519-530.

Baumann F and Kaiser KF, 1999. The Multetta Debris Fan, Eastern Swiss Alps: A 500-year Debris Flow Chronology. Arctic, Antarctic and Alpine Research 31: 128-134.

Butler DR, 2001. Geomorphic process-disturbance corridors: a variation on a principle of landscape ecology. Progress in Physical Geography 25: 237-238, DOI 10.1177/030913330102500204

Caine N, 1980. The rainfall intensity - duration control of shallow landslides and debris flows. Geographical Analysis 22A: 23-27.

Carrara PE, 1979. The determination of snow avalanche frequency through tree-ring analysis and historical records at Ophir, Colorado. Geological Society of America Bulletin 90: 773-780.

Casteller A, Christen M, Villalba R, Martinez H, Stöckli V, Leiva JC, Bartelt $\mathrm{P}, 2008$. Validating numerical simulations avalanches using dendrochronology: the Cerro Venata event in Northern Patagonia, Argentina. Natural Hazards and Earth System Sciences 8: 433443.

Decaulne A, Sæmundsson B and Petursson A, 2005. Debris flow triggered by rapid snowmelt: a case study in the Gleidarhjallli area, northwestern Iceland. Geographical Analysis A 87A: 487-500.

Dunajski A, 1998. Sukcesja roślinności na lawinisku potoku błotnokamienistego w dolinie Łomniczki w Karkonoszach - stan zaawansowania procesu po trzech latach (Vegetation succession on muddy debris flow in the Łomniczka Valley in the Karkonosze Mountains - the progress after three years). Acta Universitatis Wratislaviensis 2090, Prace Botaniczne 77: 205-217 (in Polish).

Fiorillo F. and Wilson RC, 2004. Rainfall induced debris flows in pyroclastic deposits, Campania (southern Italy). Engineering Geology 75: 263-289.

Gába Z, 1992. Mury pod Keprnikiem v červenci 1991 (Debris flows in the Keprnik massif, June 1991). Severní Morava 64: 43-50 (in Czech).

Gärtner H, Stoffel M, Lièvre I, Conus D, Grichting M and Monbaron M, 2003. Debris-flow frequency derived from tree-ring analyses and geomorphic mapping, Valais, Switzerland. Debris Flow Hazards Mitigation: Mechanics, Prediction and Assessment 1: 201207.

Huber B, 1943. Über die Sicherheit jahrringchronologischer Datierung. Holz als Roh - und Werkstoff 6: 263-268.

Ishikawa Y, Kawakami S, Morimoto Ch and Mizuhara K, 2003. Suppression of Derbis movement by forests and damage to forests by debris deposition. Journal of Forest Research 8: 37-47.

Kotarba A, 1992. High-energy geomorphic events in the polish Tatra Mountains. Geographical Analysis 74A: 121-131.

Lancaster S and Hayes S, 2003. Effects of wood on debris flow runout in small mountain watersheds. Water Resources Research 39: 121.

Lin C, Shie C, Yuan B, Shieh Y and Lee S, 2003. Impact of Chi-Chi earthquake on the occurrence of landslides and debris flows: example from the Chenyulan River watershed, Nantou, Taiwan, Engineering Geology 71: 49-61.

Malik I, 2006. Contribution to understanding the historical evolution of meandering rivers using dendrochronological methods: example of the Mała Panew River in southern Poland. Earth Surface Processes and Landforms 31: 1227-1245.

Malik I and Owczarek P, 2007. Dendrochronological records of erosion and sedimentation In a mid-mountain stream (Jeseniki Mountains - Czech Republic). TRACE - Tree Rings in Archaeology, Climatology and Ecology 5: 240-247.

May ChL, 2002. Debris flow through different forest age classes in the Central Oregon Coast Range. Journal of the American Water Resources Association 38: 1097-1113.

Perret S, Stoffel M and Kienholz H, 2006. Spatial and temporal rockfall activity in a forest stand in the Swiss Prealps - a dendrogeomorphological case study. Geomorphology 74: 219-231, DOI 10.1016 /j.geomorph.2005.08.009.

Polách D and Gába Z, 1998. Historie povodní na šumperském a jesenickém okrese (Historic foods in Šmperk and Jesenik districts). Severní Morava 75: 3-28 (in Czech).

Reid ME, Nielsen HP and Dreiss SJ. 1988. Hydrologic factors triggering a shallow hillslope failure. Bulletin of the International Association of Engineering Geology 25: 349-361.

Schweingruber FH, 1996. Tree rings and environment. Berne. Paul Haupt Verlag: 609pp.

Stoffel MI, Conus D, Grichting M, Raetzo H, Gärtner H and Monbaron M, 2005. 400 Years of Debris-Flow Activity and Triggering Weather Conditions: Ritigraben, Valais, Switzerland. Antarctic and Alpine Research 37: 387-395, DOI 10.1657/1523-0430(2005) 037[0387:YODAAT]2.0.CO;2.

Šafăr J, 2003. Olomoucko. Agentura ochrany prirody a krajiny $\check{C} R$ a EkoCentrum Brno, Praha (Olomouc Region. Agentura ochrany přirody a krajiny ČR a EkoCentrum Brno, Praha): 380pp (in Czech).

Štekl J, Brázdil R, Kakos V, Jež J and Tolasz R, 2001. Extrémní denní srážkové úhrny na území ČR v období 1879-2000 a jejich synoptické príčiny (Extreme daily precipitation in the Czech Republic area and their synoptic causes (in the period 18792000)). Český hydrometeorologický ústav, Praha: 286pp (in Czech).

Zieliński T, 2003. Catastrophic flood effects in alpine/foothill fluvial system (a case study from the Sudetes Mts, SW Poland). Geomorphology 54: 293-306, DOI 10.1016/S0169-555X(02)00362-8. 